\title{
Interpreting 'favourable conservation status' for large carnivores in Europe: how many are needed and how many are wanted?
}

\author{
Arie Trouwborst ${ }^{1} \cdot$ Luigi Boitani $^{2} \cdot{\text { John D. C. } \text { Linnell }^{3}}^{3}$
}

Received: 19 May 2016/Revised: 26 August 2016/ Accepted: 8 October 2016/

Published online: 21 October 2016

(C) The Author(s) 2016. This article is published with open access at Springerlink.com

\begin{abstract}
The EU Habitats Directive is a key biodiversity conservation instrument. It contains legal obligations for the $28 \mathrm{EU}$ member states in order to safeguard a 'favourable conservation status' (FCS) for selected species and habitat types. The crucial FCS concept itself, however, remains subject to considerable confusion regarding its proper interpretation and operationalization, impairing the Directive's effective implementation. Diminishing this confusion is the purpose of this review. It focuses specifically on large carnivores-wolf (Canis lupus), brown bear (Ursus arctos), Eurasian lynx (Lynx lynx) and wolverine (Gulo gulo). These pose particular challenges, given their low densities, transboundary populations, and human-wildlife conflict potential. Large carnivores are also the only species for which specific guidance has been adopted by the European Commission - and subsequently contested. Our methodology combines legal analysis with an understanding of the species' ecology and associated social, economic and cultural dimensions. We analyze the methods and processes through which EU law is interpreted, implemented, and enforced, by member states, European Commission, and EU Court of Justice-which is the ultimate authority regarding EU law interpretation. On that basis, we engage three particularly complex interpretation questions which are also of great practical significance: (1) the appropriate scale to achieve FCS (national or transboundary population level); (2) the respective roles of demographic, genetic and ecological factors in determining FCS; and (3) the use of extinction versus carrying capacity as benchmark.
\end{abstract}

Communicated by Marcelo F. Tognelli.

This article belongs to the Topical Collection: Biodiversity protection and reserves.

Arie Trouwborst

a.trouwborst@tilburguniversity.edu

1 Department of European \& International Law, Tilburg Law School, Tilburg University, PO Box 90153, 5000 LE Tilburg, The Netherlands

2 Department of Biology and Biotechnology, University of Rome 'La Sapienza', P.le Aldo Moro 5, 00185 Rome, Italy

3 Norwegian Institute for Nature Research, PO Box 5685, Sluppen, 7485 Trondheim, Norway 
Regarding these questions, we identify approaches that are workable and effective, as well as likely to be endorsed by the EU Court.

Keywords Favourable conservation status · FCS · Habitats Directive · Large carnivores · Law · Transboundary cooperation

\section{Introduction}

For a conservation target to be meaningful there must be a clear way of knowing when the target is reached. If there is not, this affects both the choice of conservation measures taken to achieve the target and the public perceptions of this process. However, this seemingly simple idea is challenging to operationalize in reality. This significant problem currently affects the main nature conservation regime in the European Union (EU), namely Directive 92/43 on the Conservation of Natural Habitats and of Wild Fauna and Flora of 1992 (the Habitats Directive). Although the regime seeks to achieve a 'favourable conservation status' (FCS) for certain European species and habitat types, the precise meaning of this term is subject to considerable confusion and controversy. In what follows, we try to explain and diminish this confusion and controversy, adopting the perspective of the large carnivore species wolf (Canis lupus), brown bear (Ursus arctos), Eurasian lynx (Lynx lynx) and wolverine (Gulo gulo). We begin by introducing the context, objective, outline, and broader relevance of our analysis.

\section{Context: confusion concerning FCS concept impairs effectiveness of EU nature conservation law}

The Habitats Directive is the central piece of international nature conservation legislation within the EU. It sets out legally binding obligations for the $28 \mathrm{EU}$ member states. These primarily concern the designation and protection of special areas of conservation (SACs) for listed species and habitat types, as part of the Natura 2000 protected area network, as well as the generic protection of listed species. The measures taken by member states are to ensure the maintenance or achievement of a FCS for the species and habitats involved. The Habitats Directive complements, and forms an integrated legal framework together with Directive 2009/147/EC on the Conservation of Wild Birds of 1979 (the Birds Directive), which contains similar obligations concerning the EU's wild birdlife.

Due to the clear limits it imposes on member states' domestic discretion and its high degree of enforceability at the national and the EU level (see "How interpretation questions reach the EU Court" section), the regime composed by the two Directives is generally regarded as an influential legal framework which is highly effective when compared to other international legal instruments for biodiversity conservation (Verschuuren 2003; Bowman et al. 2010; Fleurke and Trouwborst 2014; Born et al. 2015; Schoukens and Bastmeijer 2015; Bastmeijer and Trouwborst 2015; Epstein et al. 2016). Many species have profited from the protection of their habitat-nearly one-fifth of EU land territory is currently included in the Natura 2000 network-and/or the restrictions placed on their exploitation or persecution (Deinet et al. 2013). Examples where the Directives' impact on the conservation status of species can be clearly appreciated include many bird species (Donald et al. 2007; Sanderson et al. 2015; European Environment Agency 2015) and large 
carnivores like wolves and brown bears (Fleurke and Trouwborst 2014; Chapron et al. 2014).

Even so, the implementation of the regime has not been flawless, due inter alia to the Directives' delayed or faulty transposition into national law, insufficient law enforcement at the domestic level-for instance regarding the illegal killing of species protected under the Directives, such as wolves in southern Spain (Trouwborst 2014c; López-Bao et al. 2015) — and also due to confusion concerning the interpretation of certain terms and concepts contained in the Directives' provisions (Jones 2012; Wandesforde-Smith and Watts 2014; Born et al. 2015). The meaning of several of these terms and concepts has been clarified over time, chiefly through the rulings of the Court of Justice of the EU (CJEU), and also through the development of guidance documents by the European Commission. However, uncertainty persists in some key respects. The aforementioned notion of FCS is one crucial concept which continues to be subject to confusion concerning its proper interpretation and operationalization (Epstein et al. 2016; Epstein 2016).

FCS constitutes a benchmark of key significance to the practical implementation of member states' obligations under the Habitats Directive regarding site protection, generic species protection and reporting (see "A crucial yardstick for the application of the Habitats Directive" section). The European Commission-the EU body charged with facilitating and monitoring the implementation of the Directives by the member stateshas developed a measure of technical guidance concerning the concept (European Commission 2007; Linnell et al. 2008; Evans and Arvela 2011). The CJEU has touched upon the concept in several cases, albeit never comprehensively. EU member states have undertaken individual attempts to operationalize the concept. Finally, aspects of the FCS concept have been the subject of academic studies (Mehtälä and Vuorisalo 2007; Trouwborst 2014b; Epstein et al. 2016; Epstein 2016).

Nevertheless, the operationalization of FCS continues to be the subject of significant confusion, mainly concerning the proper way to set 'favourable reference values' (FRVs), and particularly how to determine what constitutes a 'favourable reference population' (FRP) in concrete instances for different species. Important questions in this regard concern the scale at which FCS should be measured (Trouwborst 2014b; Epstein 2016); the role of demographic and genetic factors in measuring FCS (Laikre et al. 2009; Epstein et al. 2016); and whether FCS should be measured upwards from extinction or downwards from carrying capacity (Epstein et al. 2016). This lack of clarity has fed controversies over whether or not FCS has been achieved for particular populations - the Scandinavian wolf population being a case in point (Chapron 2014; Epstein 2016).

Such uncertainty and controversy potentially hamper the effective application of the Habitats Directive and the achievement of the Directive's overall objective of European biodiversity conservation. Indeed, the approaches currently employed by EU member states to operationalize FCS are widely disparate (McConville and Tucker 2015). In addition, a recent study reported a worryingly poor correlation for many species between their red list status and their conservation status as reported by EU member states under the Habitats Directive (Moser et al. 2016). Because these controversies can have legal consequences for member states, they contribute to many of the conflicts surrounding biodiversity conservation in general (Hiedanpää and Bromley 2011; Redpath et al. 2013; Epstein 2016). 


\section{Objective and outline}

Understanding and diminishing this confusion and controversy regarding the FCS concept is our overall objective in this paper, in order to promote the Habitats Directive's effective application in practice. The analysis below unfolds along the following lines.

Firstly, even if the application of the Habitats Directive is influenced by a mix of ecological, socio-economic and cultural factors, we point out that the proper understanding of FCS is ultimately a legal question with a legal answer ("The FCS concept under the Habitats Directive" section). Secondly, appreciating the reasons why the confusion in this regard persists and finding ways of reducing it both hinge upon an understanding of the methods and processes through which EU law is interpreted, implemented, and enforced (provided in "Interpreting EU law: a nuanced affair" section). Thirdly, based on the above, we analyze selected issues concerning the setting of favourable reference values for large carnivores. Quantifying FCS for concrete wildlife populations is an intricate task but is nonetheless important from a practical conservation and management perspective. Our focus on large carnivores serves to illustrate the species-specific approach required when applying the FCS concept. Large carnivores are challenging species to conserve, conflictprone and occurring in transboundary populations. Moreover, large carnivores are the only species group for which specific guidance concerning the operationalization of FCS has been endorsed by the European Commission (Linnell et al. 2008). Certain elements of this guidance regarding FCS for large carnivores have subsequently been contested (Laikre et al. 2009; Epstein et al. 2016). After exploring these and other special traits of large carnivores ("FCS for large carnivores in Europe" section), we focus on three hitherto controversial questions regarding the interpretation of the FCS concept, namely the aforementioned question of scale ("The appropriate scale(s) to achieve FCS for large carnivores" section), the respective roles of demographic, genetic and ecological factors ("Demographic, genetic and ecological factors" section), and the question of avoiding extinction versus restoring to carrying capacity as benchmarks for FCS ("Extinction versus carrying capacity as benchmarks" section). Finally, we provide a synopsis of our findings and some concluding observations ("Conclusions" section).

This is a classic example of a topic where theory meets practice, and science meets policy -and indeed law. We are aware that this requires treading carefully. Law has been described as a 'means by which the distinction between nature and culture is actively produced, maintained, and complicated' (Delaney 2003; Ojalammi and Blomley 2015). That is why our analysis incorporates the distinct European context where nature and culture are thoroughly intertwined, where coexistence rather than separation of humans and wildlife is the dominant conservation paradigm, and where biodiversity conservation legislation reflects a balance struck between ecological, socio-economic and cultural values (Chapron et al. 2014; Boitani and Sutherland 2015; Boitani and Linnell 2015; Linnell et al. 2015; Carter and Linnell 2016).

\section{Broader relevance}

The questions we consider are not exclusive to the EU, and may arise in many other settings around the world where conservation targets are set. Furthermore, the FCS concept in the Habitats Directive is modeled on, and largely coincides with, the concept of FCS as incorporated and defined in the 1979 Convention on the Conservation of Migratory Species 
of Wild Animals (the Bonn Convention), a global Convention with 123 contracting parties. Thus, elements of the analysis below will be of relevance beyond Europe.

\section{Method}

In pursuing our objective, we combine legal analysis with knowledge and insights regarding the underlying ecology of the species involved and regarding the material and social aspects of the conflicts they cause with human interests.

Regarding the law, we employ standard international and EU legal research methodology (Brown and Kennedy 2000; Stone Sweet 2011; Trouwborst 2015b). This methodology consists, in particular, of the identification and analysis of relevant legal instruments and their provisions, including their interpretation according to the applicable rules from the international law of treaties as codified in the 1969 Convention on the Law of Treaties (Vienna Convention), and as refined with regard to EU law by the CJEU, while also taking account of guidance provided by the European Commission (see "The rules of the interpretation game" section). It is also relevant that all EU member states and the EU itself are contracting parties to the 1979 Convention on the Conservation of European Wildlife and Natural Habitats (Bern Convention), and that the Habitats Directive must therefore be interpreted consistently with that Convention, especially in view of the fact that the Birds and Habitats Directives are the EU's chief instruments for the implementation of the Bern Convention.

Legal methodology is still a relatively unfamiliar feature within the conservation biology literature (the scarce examples include Trouwborst 2015a; Trouwborst et al. 2015; and Epstein et al. 2016). It is generally agreed, however, that law is one of the many dimensions of the multidisciplinary endeavour that is conservation biology - and a crucial dimension at times (Freyfogle 2006). In any event, the only meaningful way to address legal issues is through the wordy process of legal analysis.

\section{The FCS concept under the Habitats Directive}

\section{A crucial yardstick for the application of the Habitats Directive}

The FCS concept pervades the Habitats Directive. The 'conservation status' of a species is defined in the Directive as the sum of the influences acting on the species concerned that may affect the long-term distribution and abundance of its population within the European territory of the EU member states [Article 1(i)]. According to the same provision, this status is taken as 'favourable' when:

(I) Population dynamics data on the species concerned indicate that it is maintaining itself on a long-term basis as a viable component of its natural habitats, and

(II) The natural range of the species is neither being reduced nor is likely to be reduced for the foreseeable future, and

(III) There is, and will probably continue to be, a sufficiently large habitat to maintain its populations on a long-term basis.'

Measures taken by member states pursuant to the Directive shall be designed to maintain or restore, at favourable conservation status, natural habitats and species of wild 
fauna and flora of Community interest, meaning those habitats and species listed in the Directive's Annexes [Article 2(2)]. At the same time, these measures must take account of economic, social and cultural requirements and regional and local characteristics [Article 2(3)].

As regards site conservation, Annex II of the Directive lists species whose conservation requires the designation of SACs as part of the Natura 2000 network. The designation and protection of these sites shall enable the habitats of the listed species to be maintained or, where appropriate, restored at a favourable conservation status in their natural range [Article 3(1)]. As regards generic species protection, member states must ensure that the exploitation, if any, of the species listed in Annex $\mathrm{V}$ of the Directive is compatible with their being maintained at a favourable conservation status [Article 14(1)]. Furthermore, the killing or capturing of strictly protected species, listed in Annex IV, may only be authorized in exceptional circumstances, one precondition being that the exemption from strict protection ('derogation') concerned is not detrimental to the maintenance of the populations of the species concerned at a favourable conservation status in their natural range [Article 16(1)]. As regards monitoring, finally, member states have a general obligation to undertake surveillance of the conservation status of the species (and habitats) covered by the Directive (Article 11).

\section{The meaning of FCS: a legal question with a legal answer}

Although perhaps not all stakeholders involved in the implementation of the Habitats Directive would feel this way, overall the Directive's provisions are actually characterized by relatively low ambiguity when compared to other legal instruments (Laffan and O'Mahoney 2004). The Directive sets out in relatively clear terms what is expected of member states - this arguably being one of the keys to its success (Bastmeijer and Trouwborst 2015). At the same time, there has to be enough flexibility in some of the key terms and concepts used in the Directive so that it can be implemented with a reasonable degree of consistency across a variety of species and habitats in a variety of regional and local contexts. Clearly, FCS is one such concept and the challenge is to strike a sensible balance between uniformity and flexibility through repeated acts of interpretation.

The striking of this balance for FCS and for similar concepts-such as 'significant effect' under the Habitats Directive, or 'recovery' under the US Endangered Species Act (Verschuuren 2003; Treves et al. 2015) - is ultimately a task of public authorities, and most especially of judges, with scientists and other stakeholders assigned an indirect role at best. The meaning of FCS is, in other words, ultimately a legal question with a legal answer. We believe that much confusion in the debate concerning FCS derives from ignoring this.

\section{Interpreting EU law: a nuanced affair}

\section{Little room for bold statements concerning 'the correct interpretation'}

When interpreting EU law, the only firm footholds are provided by the legally binding provisions (i.e., not the preambles) of the legislative acts themselves and the case law of the CJEU. Accordingly, firm statements on the correct interpretation of particular provisions in the Habitats Directive are really only justified when the text of the Directive's 
substantive provisions leaves no room for doubt, or when the issue has been unambiguously settled by the CJEU, which has the final say about the interpretation of EU law. In all other contexts-including the various interpretive issues surrounding the FCS concept dealt with in this paper-arguments may be submitted for and against particular interpretations, and we will proceed to do so, but no correct interpretation can be claimed. It is the case, however, that knowledge of the interpretive toolbox used by the CJEU in past decisions enables informed speculation regarding the interpretations that would most likely be adopted were the Court to be confronted with the interpretive issues concerned (Brown and Kennedy 2000; Stone Sweet 2011).

\section{The rules of the interpretation game}

The point of departure is the Vienna Convention. Treaty provisions must be interpreted in good faith, according to the ordinary meaning of their terms in light of a treaty's objectives, while taking into account any subsequent agreements or subsequent practice by the parties regarding the interpretation of the treaty or the application of its provisions, as well as any other relevant rules of international law (Vienna Convention, Article 31). Good examples of other such relevant rules are the aforementioned Bern and Bonn Conventions and the European Landscape Convention from 2000 (Bowman et al. 2010; Jorgensen et al. 2016; Trouwborst 2016b). When interpretation according to these guidelines still leaves the meaning of a provision ambiguous or obscure or leads to a result which is manifestly absurd or unreasonable, recourse may be had to supplementary means, including the preparatory work of the treaty and the circumstances of its conclusion (Vienna Convention, Article 32). The Habitats Directive is not itself a treaty, but an instrument of secondary EU law based on the 1958 Treaty on the Functioning of the European Union (TFEU). At any rate, the interpretive approaches habitually applied by the CJEU with respect to secondary EU law closely mirror the Vienna Convention's rules.

The teleological (objective-driven) approach has been a particularly influential interpretive method in past CJEU case law concerning the Habitats Directive, and is likely to guide the Court in the future. This approach entails an interpretation of provisions in light of the Directive's Article 2, which states that the aim of this Directive shall be to contribute towards ensuring biodiversity through the conservation of natural habitats and of wild fauna and flora within the EU, and furthermore that measures taken under the Directive shall be designed to maintain or restore species and habitats at FCS. The Court has thus interpreted exceptions to the protection of species narrowly, especially in the context of derogations from strict protection under Article 16 of the Directive (e.g., CJEU 20 October 2005, Case C-6/04; CJEU 14 June 2007, Case C-342/05).

A closely related interpretational rule is that of effet utile, or useful effect, which is also a regular feature in the Court's judgments. This favours those interpretations which give provisions of EU law their fullest effect and maximum practical impact. This may be illustrated with reference to Article 6(3) of the Habitats Directive, which states that a plan or project that might be harmful to a Natura 2000 site may in principle be authorized only if the competent member state authority has ascertained that it will not adversely affect the integrity of the site. According to the CJEU, that is the case where no reasonable scientific doubt remains as to the absence of such effects (CJEU 7 September 2004, Case C-127/02). A less stringent authorisation criterion, the Court explained, could not as effectively ensure the fulfilment of the objective of site protection intended under Article 6.

As with other courts, the work of the CJEU is case-specific and does not provide an ideal arena for science debates. Which is to say that in a given case the Court will generally 
work with the best available scientific information as presented to it by the parties to the underlying dispute. This has obvious limitations. Likewise, the case law of the Court evolves over time, along with changing scientific insights. Regarding scientific uncertainty, the CJEU has repeatedly made it plain that the Habitats Directive is to be interpreted in light of the 'precautionary principle', which errs on the side of caution in situations of uncertainty, in the best interest of the species and habitats involved (Case C-127/02; see also Article 191(2) of the Treaty on the Functioning of the European Union). Of course, what is in the best interest of a species will vary according to the specific circumstances of a case, and will be obvious in some cases and subject to debate in others. Finally, a word of caution is appropriate regarding the role of guidance documents developed by or under the auspices of the European Commission. When developing a judgment the CJEU may rely on relevant guidance provided by the Commission regarding the application of the Habitats Directive, although it will not always do so, and may indeed adopt interpretations which contradict-and thereby overrule-Commission guidance (Darpö and Epstein 2015b).

In any event, when discussing the interpretation of EU law it is crucial to clearly, carefully, and consistently distinguish between the law as it stands (lex lata), and the law as one thinks it should be interpreted (lex ferenda). This need is all the greater when, as in our paper, the primary aim is clarification, and the reduction of confusion.

\section{How interpretation questions reach the EU Court}

Interpretive questions can reach the CJEU in two ways, one corresponding with a European and the other a national route. The first involves the so-called infringement procedure under Article 258 of the TFEU, a procedure that can be instigated by the European Commission when it believes that a member state is not complying with its obligations under EU law. The allegation of non-compliance is often triggered by the submission of a complaint to the Commission by one or more concerned NGOs. After various rounds of communication between the Commission and the member state, the former may decide to submit the dispute to the CJEU. Most infringement allegations are, however, negotiated to a conclusion before reaching the Court stage. The second procedure involves a preliminary ruling under Article 267 of the TFEU, as when a national court is in doubt regarding the correct answer to a question of EU law and refers that question to the CJEU for clarification. If no further appeal is possible in the domestic proceedings involved, the national court is actually obliged to refer the matter to the EU Court. The national proceedings are then put on hold until the EU Court issues its ruling, which the national court then uses to reach its verdict. Article 267 of the TFEU thus provides a mechanism, from one judge to another, to promote a uniform application of EU law across all member states.

It is conceivable that in the future either or both of these routes will further clarify the correct interpretation of the FCS concept. A judgment shedding further light on FCS regarding large carnivores might be forthcoming, for example, if the pending infringement procedure against Sweden concerning its wolf policy is actually submitted to the Court, or if a preliminary ruling is requested from the CJEU by the Swedish judiciary (Darpö and Epstein 2015a, b; Epstein 2016). Yet, it is uncertain if and when such a scenario will play itself out. In the meantime, member states are faced with the need to apply the FCS concept, both as a general conservation objective and specifically in connection with their obligations concerning area protection, species protection, and Article 17 reporting. And 
this is where guidance provided by the European Commission has a crucial role to play; guidance that draws on the best available science and experience.

The present review is driven by the evident need to assist member states, amidst the aforementioned fundamental uncertainty, in identifying well-reasoned approaches to operationalize the FCS concept in a manner that is sufficiently consistent, workable, and likely to be endorsed by the CJEU.

\section{FCS for large carnivores in Europe}

\section{Large carnivores in Europe: a special challenge}

Across the globe, large carnivores present a special set of conservation issues, including from a legal perspective (Trouwborst 2010, 2015b; Treves et al. 2015). In Europe, wolves, brown bears, Eurasian lynx and wolverines are all covered by the Habitats Directive, although their precise legal status varies from one member state to another (see the detailed maps at www.tilburguniversity.edu/iuscarnivoris). Legal interpretation questions concerning these species and the Directive include the protection status of large carnivores expanding their populations into countries from which they had disappeared long ago (Trouwborst 2010, 2014b), or did not previously occur (Trouwborst et al. 2015); the protracted and still ongoing national and European legal disputes regarding Sweden's wolf policy (Darpö 2011; Michanek 2012; Epstein 2013; Epstein and Darpö 2013; Darpö and Epstein 2015a, b; Epstein 2016); the uncertain geographic boundaries between different legal protection regimes in parts of Europe, particularly Spain (Trouwborst 2014c); the use of zoning as a large carnivore management tool (Trouwborst 2014b); the legal status of wolf-dog hybrids (Trouwborst 2014a); and the impact of border fences on carnivores within Natura 2000 sites (Linnell et al. 2016; Trouwborst et al. 2016).

Large carnivores also clearly illustrate why the way in which FCS is made operational can vary from one species (group) to another, such that what is appropriate regarding European hamsters (Cricetus cricetus), for example-dealt with by the CJEU in 2011 (CJEU 9 June 2011, Case C-383/09) — may be quite inappropriate for wolverines. One of the fundamental characteristics of large carnivores is that they naturally occur at low population densities and move over vast areas, with individuals typically having home ranges varying from 100 to $1000 \mathrm{~km}^{2}$, and with populations tending to stretch across many sub- and inter-national jurisdictional boundaries (Linnell et al. 2001; Linnell and Boitani 2012; Chapron et al. 2014) As a consequence the population concept for large carnivores is meaningless on small scales of less than many thousands, or even many tens of thousands, of square kilometers. In Europe, the four large terrestrial predators currently occur in 33 distinct (sub)populations, no less than 28 of which are transboundary, i.e., shared between two or more countries (for the individual species the proportion of transboundary populations is 8 of 10 for wolves and bears, 10 of 11 for lynx and 2 of 2 for wolverines) (Kaczensky et al. 2013; Chapron et al. 2014). Large scale ecological processes are always associated with a unique set of practical, social and political challenges (Linnell 2015).

In addition, large carnivores tend to evoke highly polarized attitudes (Brox 2000). On the one hand, they are tightly associated with conflicts that range from depredation on livestock and pets, to competition with hunters for game, to social conflicts associated with 
wider issues that the carnivores symbolize (Linnell 2013; Redpath et al. 2013). On the other hand, large carnivores are hugely popular with the general public. The strong feelings many people have with respect to these species tend to translate into societal and political pressures often favouring radically higher or lower population levels (Darpö 2011; Borgström 2012; López-Bao et al. 2015).

\section{The 2008 Carnivore Guidelines}

These transboundary and conflict-prone characteristics led the European Commission to fund the development of specific guidance concerning the application of the Habitats Directive to large carnivores. This guidance was prepared by members of the Large Carnivore Initiative for Europe (LCIE), a Specialist Group of the IUCN Species Survival Commission, employing a science and experience based approach, incorporating the results of extensive stakeholder and EU member state consultations (workshops and meetings were held in almost every member state hosting large carnivores, and even in non-EU countries with shared populations), and input from the Habitats Committee.

The resulting Guidelines for Population Level Management Plans for Large Carnivores ('Carnivore Guidelines') were published and endorsed by the European Commission in 2008 (Linnell et al. 2008; European Commission 2008). According to the European Commission, the Carnivore Guidelines represent best practice for the management of large carnivore populations, and constitute a reference point against which [the Commission] will monitor the actions taken by the Member States in fulfilment of their obligations under the Habitats Directive (European Commission 2008). In 2015, the Guidelines were complemented by another technical document prepared by the LCIE for the European Commission, outlining several specific key actions to be taken with respect to each distinct European large carnivore population (Boitani et al. 2015).

\section{An operational definition for FCS for large carnivores}

Uniquely, the 2008 Carnivore Guidelines provide a concrete operationalization of the FCS concept for the four large carnivore species. As stated in the document itself, its development required making a link between the philosophical/political/legal concept of FCS, the biological concepts of population viability, other existing forms of categorising species status (e.g. IUCN red lists), and the specific distribution patterns and biology of the large carnivores (Linnell et al. 2008). The resulting approach is tailored to the level of each of the separate large carnivore populations, most of which, as stated above, are transboundary. Two of the key aspects of these guidelines are (1) the linking of FCS to the threat categories of the IUCN red lists, and (2) the attachment of the scale of assessment and management to the geography of biological populations irrespective of their alignment with either jurisdictional or biogeographical boundaries.

Of particular interest is the operational definition provided in the Carnivore Guidelines for FCS for large carnivores. The definition encompasses eight criteria, all of which must be met for a particular large carnivore population to be deemed to have reached a FCS. These criteria incorporate, and provide concrete interpretations of, the various elements of the FCS definition in Article 1(i) of the Habitats Directive. Given the central significance of this definition for the present article, the eight cumulative criteria are reproduced in full in Box 1. 
Box 1 Operational definition of FCS for large carnivore populations as provided in the Carnivore Guidelines (Linnell et al. 2008)

(1) Population dynamics data on the species concerned indicate that it is maintaining itself on a long term basis as a viable component of its natural habitat [Article 1 (i)]. We interpret this as implying that monitoring data indicate the population has a stable or increasing trend. We believe that a slight reduction in population size may be permitted if it is a result of response to changes in prey density or habitat quality that are not caused by direct human action, unless conditions for derogations apply. All segments of a population should have stable or positive trends, and not just the population as a whole. And,

(2) The natural range of the species is neither being reduced nor is likely to be reduced for the foreseeable future [Article 1 (i)]. We interpret this as implying that the overall distribution of the population is stable or increasing. And,

(3) There is, and will probably continue to be, a sufficiently large habitat to maintain its population on a long-term basis [Article 1 (i)]. We interpret this to imply that the quality and continuity of habitat should be sufficient, and have a stable or increasing trend. And,

(4) The population size and range are equal to or greater than when the Directive came into force. And,

(5) The favourable reference population size has been reached. According to our proposal this will be set at levels greater than those regarded as being viable using the IUCN red list criteria D or E. And,

(6) The favourable reference range has been occupied. And,

(7) Connectivity within and between populations (at least one genetically effective migrant per generation) is being maintained or enhanced. And,

(8) Member States shall undertake surveillance of the conservation status of the natural habitats and species referred to in Article 2 with particular regard to priority natural habitat types and priority species [Article 11] and Member States shall establish a system to monitor the incidental capture and killing of the animal species listed in Annex IV (a) [Article 12.4]. These statements combine to indicate that the population should be subject to a robust monitoring program.

For a population to be regarded as having reached a FCS, all eight criteria must be satisfied.

\section{The appropriate scale(s) to achieve FCS for large carnivores}

\section{The million euro question: FCS at what geographic scale?}

Member states' conceptions as to what, generally speaking, constitutes a favourable reference population (FRP) for determining FCS vary considerably. These include a threshold of 5000 individuals in a functionally connected population (Flanders, Belgium); 500 reproductive units (the Netherlands); 500 functionally connected mature individuals at the biogeographical region level (Denmark); and a range of much fuzzier approaches, employed by most member states (McConville and Tucker 2015). The key question raised here is the scale at which FCS is to be measured and achieved: at the level of a biogeographical region, a member state's territory, a population, a Natura 2000 site, or a combination of these? Interestingly, the answer to this question appears to vary not only according to the species, but also, it would seem, according to the particular contextreporting, site protection, or generic species protection (Trouwborst 2010).

\section{FCS in the context of reporting}

As regards reporting, member states periodically submit reports on the conservation status of species and habitat types under Article 17 of the Habitats Directive. This is done per biogeographical region, at the national level (European Commission 2007; Evans and 
Arvela 2011). For species occurring in transboundary populations, however, the member states concerned have the option of undertaking a joint assessment of current status at the scale of the population, although each member state also has to report its results individually (Evans and Arvela 2011). According to a guidance document on Article 17 reporting, such joint assessments should be carried out primarily in cases where there is a certain level of cooperation and understanding of the management needs and approaches for the species concerned, expressly mentioning large carnivore populations as an example (Evans and Arvela 2011). However, to date no member states have availed themselves of this joint assessment option.

\section{FCS in the context of site protection}

As regards habitat protection, the prevailing position seems to be that a FCS is to be safeguarded primarily at the national level, although there are also some indications that FCS might need to be attained even at the level of individual Natura 2000 sites (Trouwborst 2014b; Cliquet et al. 2015). The default position of the European Commission in this regard is that:

The directives impose obligations on the Member States as such, which implies that-inter alia-favourable conservation status of species and habitat types of Community interest should be achieved at Member State level. This in turn implies that where favourable conservation status is achieved at the national level, the Member State does not necessarily have to achieve good conservation status in each individual site. However, as a general rule in all Natura 2000 sites, Member States must avoid the deterioration of the habitats of Community interest and the habitats of species of Community interest for which a site was designated. (European Commission 2011)

Interestingly, the CJEU determined in 2013 that in order for the integrity of a site as a natural habitat not to be adversely affected for the purposes of the second sentence of Article 6(3) of the Habitats Directive the site needs to be preserved at a favourable conservation status (CJEU 11 April 2013, Case C-258/11). The Court reaffirmed this position a year later (CJEU 15 May 2014, Case C-521/12). These cases, however, concerned localized occurrences of particular habitat types (limestone pavement and molinia meadows, respectively). When presented with a case concerning a site designated for wolves, bears or other large carnivores, the Court can certainly not be expected to interpret the Directive as requiring a FCS for such wide ranging species at the level of the site. Such an interpretation, to cite the Vienna Convention, would be unreasonable or even manifestly absurd, given that no single protected area in Europe is large enough to independently host a viable large carnivore population, and most can hardly contain the ranges of individuals (Linnell et al. 2001, 2008; Boitani and Ciucci 2009).

\section{FCS in the context of species protection}

As regards generic species protection, the central provision for our present purposes is the aforementioned Article 16, according to which a derogation from strict protection may be granted only if it is not detrimental to the maintenance or achievement of the species' populations at a FCS. Here, the chief question is whether conservation status ought to be assessed at the (sub)national level or the transboundary population level-or both (Trouwborst 2014b; Epstein et al. 2016; Epstein 2016). The scarce case law of the CJEU 
on this count may prima facie be taken to support the former, (sub)national approach. In a case concerning the conservation and management of wolves in Finland, both parties to the dispute (the European Commission and Finland) assessed the conservation status of wolves at the national level within Finland, without regard to the Russian part of the contiguous Karelian wolf population, and the Court likewise determined that at the time of the dispute the conservation status of the wolf in Finland was not favourable (CJEU 14 June 2007, Case C-342/05). To switch our focus briefly from large carnivores to a small herbivore, the Court took a similar approach in the aforementioned French hamster case of 2011 (Case C-383/09), addressing the hamster's conservation status within France without considering the contiguous population across the border in Germany and further eastward (Clément 2015).

Notably, the Finnish wolf case was decided by the CJEU prior to the publication of the Carnivore Guidelines in 2008. Since then, the leading paradigm with regard to wolves and other large carnivores has become the transboundary population level approach (Linnell and Boitani 2012). Already in a 2007 guidance document on strict protection, the European Commission had expressly advocated the view that, in connection with Article 16 derogations, the killing of individuals of a wide-ranging large carnivore will need to be evaluated at population level (transboundary where applicable) (European Commission 2007). The implicit consequence of this approach is expressly stated in the Carnivore Guidelines themselves, namely that adopting the transboundary population as a benchmark for FCS could exempt certain member states from the obligation to achieve a FCS for large carnivores at the national level (Linnell et al. 2008).

\section{The downside of adopting the transboundary population as a FCS benchmark}

The question can be more clearly framed: for the large carnivore species occurring within its borders, must a member state achieve FCS at the national level, or can it meet the legal requirements of the Directive by making a meaningful national contribution to the achievement of FCS for the shared transboundary population(s) to which the large carnivores on its own territory belong?

The legal snag with the latter alternative is that the Habitats Directive's collective goal of European biodiversity conservation is ultimately translated into individual obligations of member states. Even where these obligations are carried out by several member states in a coordinated fashion, for instance regarding a shared lynx population, in legal terms each member state remains individually accountable for its own performance. In this regard the Habitats Directive is representative of the state of international wildlife law more generally where, despite some interesting exceptions, the realization of the notion of shared rather than individual state responsibility for achieving conservation objectives is still in an early stage (Trouwborst 2016a). This has a lot to do with the obvious need to keep states from hiding behind the performance of others, for instance by using an abundance or positive trend of a species abroad as an incentive to tone down its own ambitions and efforts to conserve the species within its own territory (Shine 2005). For precisely that reason the CJEU generally does not grant member states much room for relying on conservation efforts across their borders, focusing instead on their own performance under the Directive (CJEU 13 December 2007, Case C-418/04).

This need to ensure national accountability may also explain why the European Commission, acting in its capacity as EU law enforcer in the Swedish wolf infringement procedure, has not emphasized a transboundary population level approach to FCS for the wolf. For example, in one of its letters the Commission notes that Sweden and the 
Commission agree that the Swedish population is not in favourable conservation status, while failing to refer to the transboundary Scandinavian population, which also includes animals in Norway (European Commission 2010). As discussed below, however, this approach may not be as inconsistent as it may appear at first sight.

\section{The downside of adopting the national population as a FCS benchmark}

Having thus identified a potential snag affecting the use of the transboundary population as FCS benchmark, we now draw attention to the fact that a (sub)national approach to FCS for large carnivores is affected by problems of its own. Notably, the aforementioned indications that could be taken to suggest that a national benchmark must be used for FCS of large carnivores - the Finnish wolf case and the Commission's position in the Swedish infringement procedure-both concern large countries where size and habitat availability make it conceivable that they could independently harbour large carnivore populations meeting the requirements for FCS within their own borders. However, when considering the scenario of lynx or wolves in the Benelux countries it is almost impossible to imagine these countries having enough habitat or space to contain enough individuals to attain FCS in isolation (or not at least if 'favourable' is indeed in any way attached to absolute standards associated with population viability) (Linnell et al. 2001, 2008; Linnell and Boitani 2012). An associated issue even concerns Swedish wolves. These are highly inbred, such that their long term viability depends on immigration from Finland far more than it does on the size of the population within Sweden (Laikre et al. 2013; Liberg et al. 2015).

The Carnivore Guidelines unequivocally recognize this complicated state of affairs when stating that many (maybe most) countries will never be able to host enough individuals to have a population that can reach FCS (Linnell et al. 2008). In the words of the European Commission, it is difficult, if not impossible, for one Member State to manage and protect its large carnivores in the absence of concerted and convergent actions being taken by its neighbours (European Commission 2008). Likewise, the CJEU may be expected to avoid interpretations of the Habitats Directive which cause a direct and obvious clash between the law and ecological reality (Trouwborst 2011; Linnell and Boitani 2012; Trouwborst 2014d). What is more, the Court can be trusted to avoid interpretations which require member states to do the impossible. Indeed, demanding the impossible is the very opposite of legal interpretation in good faith, and nothing could be more manifestly absurd or unreasonable (Vienna Convention; see "The rules of the interpretation game" section above). In sum, it is fanciful to imagine an interpretation of the Habitats Directive by the CJEU that strictly requires the achievement of a FCS for large carnivores at the national level in all member states where these species occur.

A related, although opposite, problem of scale exists for some other countries that have highly fragmented populations of a carnivore species with large distances of non-passable habitat between them. An example would be Italy's bears, where two small populations occur. One is in the central Apennines, centered around Abruzzo National Park, with a second in the Alps, over $500 \mathrm{~km}$ away. It is almost inconceivable that these populations will reconnect in the near future, due to virtually irreversible changes in and fragmentation of the relevant habitat. The Alpine population makes no practical contribution to the conservation status of the Abruzzo population, meaning that it makes no sense to assess the conservation status of bears in Italy as a whole, and any attempt to do so would grossly overestimate their viability. 


\section{Population level management plans as the silver bullet}

Thus, the most appropriate interpretation of the issue of scale regarding FCS for large carnivores has to be the result of navigating carefully between the various snags just identified. This points to the need to come up with a solid and workable conservation approach that combines biological realism with a way to achieve the legal aims of the Directive and enabling verifiable compliance by member states with their obligations concerning large carnivores. This need is precisely the reason why the Carnivore Guidelines were developed (Linnell et al. 2008; Linnell and Boitani 2012).

The Carnivore Guidelines adopt the (transboundary) population as the most appropriate scale on which to focus conservation status assessments (Linnell et al. 2008). However, they make this conditional on the adoption and implementation of a joint management plan or equivalent formalized cooperative structure, between the competent authorities of all countries involved, for each large carnivore population. This way, all countries sharing the population should contribute to ensuring between them that the population reaches and maintains FCS (Linnell et al. 2008). The Guidelines provide a detailed template regarding the substance of such cooperation agreements. According to the European Commission, effective management of large carnivore populations which are shared between Member States can only be achieved through shared and coordinated management plans as described in the[se] guidelines (European Commission 2008). Of course, not all large carnivore populations are transboundary. To return to the Italian bear example given above ("The downside of adopting the national population as a FCS benchmark" section), under the Carnivore Guidelines, Italy would have sole responsibility for ensuring a FCS of the isolated Apennine population, in addition to making a contribution together with Austria and Slovenia to ensure a FCS for the Alpine population.

The Standing Committee of the Bern Convention, the Convention's main decisionmaking body in which all parties are represented, has similarly called on the contracting parties to the Convention to reinforce cooperation with neighbouring states in view of adopting harmonized policies towards management of shared populations of large carnivores, taking into account the best practice in the field of management of populations of large carnivores, with express reference to the EU Carnivore Guidelines (Recommendation No. 137 (2008)). Incidentally, the Guidelines' template may serve as a blueprint for international cooperation at the transboundary population level for other species and regions as well (Selier et al. 2016).

According to the Carnivore Guidelines, each transboundary management plan is expected to clarify what will be understood as a FRP and a 'favourable reference range' (FRR) for the population concerned, and to set out the actions to be taken by each participating country to achieve or maintain those values (Linnell et al. 2008). Regarding removals of large carnivores from the population, including derogations from strict protection, the transboundary management plan should set a population level limit for the number of individuals that can be removed per year, while ensuring that any actual removal of large carnivores is coordinated between all countries sharing the population, and that the evaluation of the 'no detrimental effect on FCS'-test for Article 16 derogations is conducted at the population level (Linnell et al. 2008). This would give each individual member state more flexibility to allow derogations from strict protection where deemed desirable, than would have been the case under the application of a national approach to determining FCS (Trouwborst 2014b). Indeed, this can be seen as an important 'carrot' to coax member states into developing joint population level management. 
Conversely, however, until a fully-fledged and well-functioning transboundary plan is in place and provides for the enumerated safeguards, the national level would be the default scale for assessing FCS for large carnivore populations and for assessing the compliance of the member states involved with their obligations under the Habitats Directive-resulting in significantly more onerous and potentially infeasible requirements for those member states. Viewed in this light, employing a national yardstick in the Swedish infringement proceedings would seem appropriate after all, given that the current degree of cooperation between Sweden and Norway regarding wolves does not meet the standards set out in the Carnivore Guidelines and that the potential connection to Finland is too distant and infrequent to contribute to demographic viability (Trouwborst 2010; Blanco 2013; Trouwborst 2014b).

We are comfortable, then, in recommending the approach laid out in the Carnivore Guidelines as the appropriate way forward for applying the FCS concept to large carnivores in Europe. Not only is this a realistic and science-based approach reflecting extensive stakeholder involvement, but it also appears to represent the only way to avoid the two serious problems of legal interpretation outlined above - and appears therefore the most 'CJEU-proof' of all available alternatives.

\section{Demographic, genetic and ecological factors}

\section{Demographic and genetic factors in the FCS assessment}

The Carnivore Guidelines (Linnell et al. 2008) aimed to provide clear quantitative guidance about the number of individuals that were needed to achieve FCS, in an effort to give EU member states a consistent basis for the implementation of the Habitats Directive regarding large carnivores. This was done by linking the concept of FCS to the globally recognized threat assessment criteria adopted by the IUCN in its red list assessments. The rationale was that a population must be considered to be at FCS if it was, inter alia, outside the categories regarded as being at threat under IUCN criteria. These criteria remain the leading (only) internationally established set of criteria for this form of assessment. They are based on the discipline of population viability analysis (IUCN Standards and Petitions Subcommittee 2016). Functionally, they base an assessment of extinction probability on the demographics of a population and typically do not expressly take into account genetic issues unless they have a direct impact on demographic parameters (birth and death rates) (IUCN Standards and Petitions Subcommittee 2016).

This use of the IUCN criteria to inform FCS assessments has provoked criticism from various authors (Laikre et al. 2009; Epstein et al. 2016) who claim that the concept of FCS cannot be satisfied by such a 'low' level of conservation ambition, and that FCS presupposes genetic viability in addition to demographic viability. Laikre et al. (2009) claim in this regard that the Carnivore Guidelines completely disregard the effective population size required for long-term viability. Likewise, Epstein et al. (2016) argue that the Carnivore Guidelines focus too narrowly on demographic viability, submitting that the guidelines' recommendation to use criterion $E$ is wholly unjustified and should be rejected. Both criticisms are unfortunate misrepresentations of the Carnivore Guidelines.

To be sure, the Habitats Directive makes no direct link to population viability or IUCN criteria as a basis for determining FCS. The relevant guidance lies in the definition of FCS in Article 1(i) which requires that population dynamics data on the species concerned 
indicate that it is maintaining itself on a long-term basis as a viable component of its natural habitats. The reference to population dynamics data appears to align with the rationale of the IUCN criteria, which are based largely on demographic parameters. And the Article 17 reporting guidelines (Evans and Arvela 2011) state that population viability analysis can be used to assess FRP if it is available. The critics, however, point to the language dealing with conservation for the long-term and a species as a viable component of its natural habitats. IUCN criteria typically assess viability over 100 year time horizons. Certainly, if the term long-term is interpreted as referring to periods longer than this, viability will depend on levels of genetic variation being maintained. This dimension of genetic variation is also specifically mentioned in the Article 17 reporting guidelines (Evans and Arvela 2011), although its consideration is carefully presented as an option rather than a rule of thumb. The reporting guidelines state that it may be relevant to consider the genetic structure of a species, while highlighting that [i]n many cases little information is available (Evans and Arvela 2011).

In any event and contrary to what Laikre et al. (2009) and Epstein et al. (2016) have suggested, the issue of genetic viability is not ignored in the 2008 Carnivore Guidelines. The Guidelines acknowledge that minimum viable populations (MVPs), which are mainly based on demographic considerations are unlikely to be sufficient to achieve the levels of genetic viability or ecological viability that we assume are implied in the intentions of the Habitats Directive (Linnell et al. 2008). Thus, the Carnivore Guidelines recognize that the purpose of the Habitats Directive, as Epstein (2016) recently phrased it, is to promote flourishing rather than merely to prevent extinction. Accordingly, the Guidelines recommend that to achieve the level of a FRP a large carnivore population must, among other things, be at least as large (and preferably much larger) than an MVP, as defined by the $I U C N$ criterion $E$ (extinction risk based on a quantitative $P V A$ with $<10 \%$ extinction risk in 100 years), or criterion D (number of mature individuals) (Linnell et al. 2008). Besides, as Epstein (2016) also notes, the application of IUCN Criterion E may already require that genetic factors are taken into account (IUCN Standards and Petitions Subcommittee 2016). Furthermore, in the context of the favourable reference range (FRR) the Carnivore Guidelines have specifically translated the need for genetic viability into a requirement to ensure connectivity between populations, which is essential for gene flow. This incorporates the same rule of thumb as is emphasized by Laikre et al. (2009), namely ensuring at least one genetically effective migrant per generation (Linnell et al. 2008). Thus, rather than ignoring its importance, the Carnivore Guidelines have elevated the notion of genetic viability to a level that embraces multiple populations, in effect requiring connectivity across much of the European continent (Linnell et al. 2008). In any event, it would be even less practical for most European countries to contain enough individuals of these low density and wide ranging species to autonomously achieve populations that are genetically viable than it is to obtain demographic viability (see "The downside of adopting the national population as a FCS benchmark" section above), something which Laikre et al. (2009), Epstein et al. (2016) and Epstein (2016) acknowledge.

Thus, encouragingly, the conclusion seems warranted that the critical opinions voiced by these authors concerning the approach set forth in the Carnivore Guidelines regarding FCS for large carnivores may be ascribed to misunderstanding rather than disagreement.

\section{Ecological factors in the FCS assessment}

Another aspect of the statement that a species should be a viable component of its natural habitats is far less clear. On one level, this statement could appear to imply simply that the 
species should be present in its habitat at a level which is viable. However, we agree with Epstein et al. (2016) that it could also be interpreted to mean that the Habitats Directive aims to ensure the preservation of ecological processes as well as species. Large carnivores are certainly associated with a wide range of ecological processes through their roles as predators, with direct and indirect effects on prey, and thereby potential cascading impacts on habitats. The impacts that predators have on their prey are, however, highly variable and context dependent. This is especially true in human-dominated landscapes, as in Europe, where humans have by far the strongest impact at all trophic levels. Humans modify vegetation structure through forestry and agriculture, they influence prey through hunting, supplementary feeding and providing livestock, and they influence large carnivores directly through accidental and deliberate mortality, and indirectly through habitat fragmentation (Andersen et al. 2006; Boitani and Linnell 2015; Dorresteijn et al. 2015).

The implication is that any role large carnivores will have in the ecology of European habitats is going to be heavily modified by humans, removing any possible benchmark of 'naturalness', and thus making it very hard to assess what level of interaction is regarded as being sufficient. Our best interpretation is that the criterion of a viable component of its natural habitats is simply a call to keep numbers at a level higher than minimum levels, in the same way that the various existing guidelines state that FRP should be larger than MVPs.

\section{Precaution and pragmatism}

In the absence of serious conflicts of interest the benefit of the doubt regarding all these interpretive issues could be given to the species, in accordance with the precautionary principle, potentially leading to requirements for very large population sizes. However, particularly in light of the effet utile doctrine, considerations of practical feasibility may influence the Court's stance on the operationalization of FCS in a given case. For instance, it is not self-evident what the position of the CJEU would be when confronted with a choice between a consistent and workable approach to FCS such as the one outlined in the Carnivore Guidelines, and an approach which is theoretically more ambitious from a conservation perspective but is so complex and controversial that it is difficult to apply in a meaningful manner in practice, e.g., an approach emphasizing ecological functionality, which is notoriously difficult to quantify.

An added consideration is that large carnivores are associated with many conflicts (Linnell 2013) and that high population targets are therefore very controversial across Europe. The fear among many conservationists is that pushing too hard for ambitious goals will lead to a backlash in public opinion, weakening the species' conservation in the long term. We doubt, however, that this particular concern is likely to influence the position of the CJEU in a given case involving the interpretation of FCS for large carnivores.

\section{Extinction versus carrying capacity as benchmarks}

\section{Measuring FCS upward from extinction or downward from carrying capacity}

Until recently there was an apparent consensus that FCS should be defined and operationalized at some level above the absolute lower threshold of extinction, following the same logic as the IUCN red list criteria. The discussion was about how much above 
'extinct' it should be. In a recent paper, however, Epstein et al. (2016) have argued in favour of a radically different approach whereby FCS would be defined as a deviation from carrying capacity instead of extinction. This was motivated by a desire to place emphasis on the ecological function of carnivores, an emphasis the authors consider to be implied by the as a viable component of its natural habitats language of the Directive's FCS definition. The idea has several attractive aspects, not the least being that it would scale a given country's required level of ambition in carnivore conservation to its available habitat. The approach has already been operationalized, most notably in Poland with regard to wolves (Jędrzejewski et al. 2008). With reference to this Polish example, the Article 17 reporting guidelines note-in a descriptive, not prescriptive manner-that some countries have used the concept of carrying capacity together with estimates of the range or suitable habitat to estimate a FRP (Evans and Arvela 2011).

\section{Carrying capacity approach unworkable as general rule}

On closer examination, however, using carrying capacity as benchmark would not make a good general rule. It is not clear, for example, how carrying capacity for large carnivores should be defined in human-dominated landscapes. Carrying capacity is very hard to define anyway a priori and without some experimentation, and it is likely to shift over time. For carnivores, it is likely to be influenced heavily by the densities of wild and domestic prey. One question would be whether domestic prey should be included or not? In some parts of Europe, carnivores largely subsist on domestic prey, which they obtain either through predation or scavenging. Excluding such prey from the equation would thus effectively lead to estimates of carrying capacity well below present carnivore densities. Similarly, many populations of wild ungulates in Europe today are at record high densities because they benefit directly from supplementary feeding and indirectly from improved foraging opportunities as a result of agriculture and forestry. A further consideration is that most of Europe's bears (in the Dinaric and Carpathian mountains) are fed (Kavčič et al. 2015). To what extent should these artificially enhanced prey/forage resources be included in carrying capacity? If they are excluded, then many carnivore populations are probably above carrying capacity, especially bears in southeastern Europe. Indeed, if the emphasis is going to be placed on the 'natural habitats' part of achieving FCS, a good argument could actually be made that there is no need to include large carnivores in any of the manmade habitats that constitute the vast majority of Europe's surface. A final issue concerns the selection of the proportion of carrying capacity to be used as a threshold. Epstein et al. (2016) propose $50 \%$, but this is as subjective as the extinction risk criteria lying behind IUCN red list criteria.

\section{Legal uncertainty persists}

While we thus do not think carrying capacity can serve as a general guideline for determining FCS for large carnivores, the debate about extinction versus carrying capacity as benchmarks does underline the massive uncertainty as to what the architects of the Habitats Directive had in mind when they said that species need to be viable components of their natural habitats. From a legal perspective it is hard to predict with any certainty that the CJEU would have a preference for either approach. While Epstein et al. (2016) claim that using carrying capacity is more 'logically consistent' than using extinction as benchmark, they-rightly-stop short of claiming that this would be the only correct legal 
interpretation. Subsequently, Epstein (2016) has said that the choice of approach in this regard seems to be left to the discretion of the Member States.

\section{Conclusions}

\section{Synopsis}

Some findings of the preceding review can be summarily stated as follows:

First, despite the relevance of a range of scientific, cultural and socio-economic variables, the meaning of the FCS concept under the Habitats Directive is ultimately a legal question with a legal answer and hinges, therefore, on a proper understanding of EU law interpretation.

Second, given the nature of EU law, the closest we can hope to get to a correct interpretation of FCS is to identify the interpretation most likely to be endorsed by the CJEU. Other conclusive statements are not warranted at the present stage. The discourse regarding FCS needs to distinguish clearly between the law as it stands and the law as it should be in one's own opinion.

Third, regarding the question of geographic scale, the superior interpretation, bearing in mind the preceding caveat, is that the national level is the default for the achievement of FCS for large carnivore species, including where the animals are part of transboundary populations. However, once a fully-fledged population level management plan has been developed by the countries involved and becomes operational, the transboundary population is an appropriate FCS benchmark.

Fourth, regarding the question of demographic and genetic factors, the operational definition of FCS provided in the Carnivore Guidelines, which incorporates demographic as well as genetic factors, would appear to be both CJEU-proof and workable.

Fifth, regarding the question of using extinction versus carrying capacity as benchmark for determining FCS, the latter seems to be practically unsuitable to serve as a general rule in the European large carnivore context.

\section{Carnivore Guidelines provide surest way forward through legal FCS quagmire}

How to interpret and operationalize the FCS concept for different species and in different contexts remains one of the most vexing and persistent questions regarding the implementation of the Habitats Directive. Large carnivores pose particularly intricate challenges. The Carnivore Guidelines offer a way out of the labyrinth of legal interpretation issues governing the Directive's implementation, and a constructive and pragmatic way forward for the conservation and management of large carnivores in Europe. Given that the Guidelines were developed by leading experts on European carnivores, and through an extensive consultation process with stakeholders and the competent authorities in member states, they have considerable weight as the state-of-the-art guidance, at least until the CJEU confirms or rejects what they recommend. Furthermore, we have identified no inconsistencies or legal incompatibilities between the Carnivore Guidelines and other guidance developed by the European Commission, including the subsequently issued Article 17 reporting guidelines (Evans and Arvela 2011). The actual development and implementation of cooperative management structures at the transboundary population 
level is a slow process (Blanco 2013) - and understandably so, given the challenges involved (Linnell and Boitani 2012). It does, however, seem to be the only way to go.

\section{Questions of 'how many do you need?' and 'how many do you want?' should not be mixed}

Finally, FCS, however it is determined, represents a legally binding minimum standard motivated primarily by European level conservation concerns. However, in any given part of Europe, the actual population sizes (targets) for large carnivores deemed to be appropriate will be influenced not only by legal and ecological considerations but also by socioeconomic and cultural considerations. Hence the importance of distinguishing between the question of how many carnivores are needed to satisfy obligations under the Habitats Directive and the question of how many carnivores are wanted to satisfy national level ambitions. The former constitutes a legally binding minimum, and must be set in accordance with the demands of the European legal framework. The latter is subject to national deliberative processes, which vary considerably across the EU and over time, and is, therefore, a much more open-ended question. Attempting to find European support for national level decisions while failing to distinguish between the two questions, has produced unnecessary confusion and conflict (Hiedanpää and Bromley 2011). In a European context where nationalism is resurging, a more sustainable and constructive strategy can only be achieved if the distinction is observed.

Acknowledgments JDCL was funded by the Research Council of Norway (Project 212919) and the Norwegian Environment Agency. AT was funded by the Netherlands Organization for Scientific Research, as part of the project 'Ius Carnivoris' (Project 452-13-014, www.tilburguniversity.edu/iuscarnivoris). Very helpful comments by the anonymous reviewers and by Floor Fleurke and Han Somsen are gratefully acknowledged. The authors are grateful to all their colleagues in the Large Carnivore Initiative for Europe for fruitful discussions over many years.

\section{Compliance with ethical standards}

Conflict of interest The authors declare that they have no conflict of interest.

Open Access This article is distributed under the terms of the Creative Commons Attribution 4.0 International License (http://creativecommons.org/licenses/by/4.0/), which permits unrestricted use, distribution, and reproduction in any medium, provided you give appropriate credit to the original author(s) and the source, provide a link to the Creative Commons license, and indicate if changes were made.

\section{References}

Andersen R, Linnell JDC, Solberg EJ (2006) The future role of large carnivores on terrestrial trophic interactions: the northern temperate view. In: Danell K, Bergström R, Duncan P, Pastor J (eds) Large herbivore ecology, ecosystem dynamics and conservation. Cambridge University Press, Cambridge, pp 413-448

Bastmeijer CJ, Trouwborst A (2015) Zijn de Vogelrichtlijn en Habitatrichtlijn fit? Een bespreking van de krachtige kenmerken en kritiekpunten van de EU Vogelrichtlijn en Habitatrichtlijn tegen de achtergrond van de EU fitness check [Are the Birds Directive and Habitats Directive fit? A discussion of characteristics and criticisms of the EU Birds and Habitats Directives against the background of the EU fitness check] (in Dutch). A Tilburg Law School report prepared for WWF-Netherlands

Blanco JC (2013) Towards a population level approach for the management of large carnivores in Europe: challenges and opportunities. Eur Comm, Brussels

Boitani L, Ciucci P (2009) Wolf management across Europe: species conservation without boundaries. In: Musiani M, Boitani L, Paquet PC (eds) A new era for wolves and people: wolf recovery, human attitudes, and policy. University of Calgary Press, Calgary, pp 15-40 
Boitani L, Linnell JDC (2015a) Bringing large mammals back: large carnivores in Europe. In: Pereira HM, Navarro LM (eds) Rewilding European landscapes. Springer, Cham, pp 67-84

Boitani L, Sutherland WJ (2015b) Introduction special section: conservation in Europe as a model for emerging conservation issues globally. Conserv Biol 29:975-977

Boitani L, Alvarez F, Anders O, Andren H, Avanzinelli E, Balys V, Blanco JC, Breitenmoser U, Chapron G, Ciucci P, Dutsov A, Groff C, Huber D, Ionescu O, Knauer F, Kojola I, Kubala J, Kutal M, Linnell J, Majic A, Mannil P, Manz R, Marucco F, Melovski D, Molinari A, Norberg H, Nowak S, Ozolins J, Palazon S, Potocnik H, Quenette P, Reinhardt I, Rigg R, Selva N, Sergiel A, Shkvyria M, Swenson J, Trajce A, Von Arx M, Wolfl M, Wotschikowsky U, Zlatanova D (2015) Key actions for large carnivore populations in Europe. A Large Carnivore Initiative for Europe report prepared for the European Commission (contract 070307/2013/654446/SER/B3)

Borgström S (2012) Legitimacy issues in Finnish wolf conservation. J Environ Law 24:451-476

Born C, Cliquet A, Schoukens H, Misonne D, Van Hoorick G (eds) (2015) The Habitats Directive in its EU environmental law context: European nature's best hope?. Routledge, London

Bowman M, Redgwell C, Davies P (2010) Lyster's International Wildlife Law, 2nd edn. Cambridge University Press, Cambridge

Brown LN, Kennedy T (2000) The Court of Justice of the European Communities, 5th edn. Sweet \& Maxwell, London

Brox O (2000) Schismogenesis in the wilderness: the reintroduction of predators in Norwegian forests. Ethnos 65:387-404

Carter NH, Linnell JDC (2016) Co-adaptation is key to coexisting with large carnivores. Trends Ecol Evol 31:575-578

Chapron G (2014) Challenge the abuse of science in setting policy. Nature 516:289

Chapron G, Kaczensky P, Linnell JDC, von Arx M, Huber D, Andrén H, López-Bao JV, Adamec M, Álvares F, Anders O, Balčiauskas L, Balys V, Bedő P, Bego F, Blanco JC, Breitenmoser U, Brøseth H, Bufka L, Bunikyte R, Ciucci P, Dutsov A, Engleder T, Fuxjäger C, Groff C, Holmala K, Hoxha B, Iliopoulos Y, Ionescu O, Jeremić J, Jerina K, Kluth G, Knauer F, Kojola I, Kos I, Krofel M, Kubala J, Kunovac S, Kusak J, Kutal M, Liberg O, Majić A, Männil P, Manz R, Marboutin E, Marucco F, Melovski D, Mersini K, Mertzanis Y, Mysłajek RW, Nowak S, Odden J, Ozolins J, Palomero G, Paunović M, Persson J, Potočnik H, Quenette P-Y, Rauer G, Reinhardt I, Rigg R, Ryser A, Salvatori V, Skrbinšek T, Stojanov A, Swenson JE, Szemethy L, Trajçe A, Tsingarska-Sedefcheva E, Váňa M, Veeroja R, Wabakken P, Wölfl M, Wölfl S, Zimmermann F, Zlatanova D, Boitani L (2014) Recovery of large carnivores in Europe's modern human-dominated landscapes. Science 346:1517-1519

Clément M (2015) Global objectives and scope of the Habitats Directive: What does the obligation of result mean in practice? The European hamster in Alsace. In: Born C, Cliquet A, Schoukens H, Misonne D, Van Hoorick G (eds) The Habitats Directive in its EU environmental law context: European nature's best hope?. Routledge, London, pp 9-20

Cliquet A, Decleer K, Schoukens H (2015) Restoring nature in the EU: the only way is up? In: Born C, Cliquet A, Schoukens H, Misonne D, Van Hoorick G (eds) The Habitats Directive in its EU environmental law context: European nature's best hope?. Routledge, London, pp 265-284

Commission European (2007) Guidance document on the strict protection of animal species of Community interest under the Habitats Directive 92/43/EEC. Eur Comm, Brussels

Darpö J (2011) Brussels advocates Swedish grey wolves: on the encounter between species protection according to Union law and the Swedish wolf policy. SIEPS European Policy Analysis 2011(8):1-19

Darpö J, Epstein Y (2015a) Under fire from all directions: Swedish wolf management hunting scrutinized by Brussels and at home. In: Born C, Cliquet A, Schoukens H, Misonne D, Van Hoorick G (eds) The Habitats Directive in its EU environmental law context: European nature's best hope? Routledge, London, pp 348-372

Darpö J, Epstein Y (2015b) Thrown to the wolves - Sweden once again flouts EU standards on species protection and access to justice. Nord Environ Law J 7:7-20

Deinet S, Ieronymidou C, McRae L, Burfield IJ, Foppen RP, Collen B, Böhm M (2013) Wildlife comeback in Europe: the recovery of selected mammal and bird species. Zoological Society of London Birdlife International and European Bird Census Council, London

Delaney D (2003) Law and nature. Cambridge University Press, Cambridge

Donald PF, Sanderson FJ, Burfield IJ, Bierman SM, Gregory RD, Waliczky Z (2007) International conservation policy delivers benefits for birds in Europe. Science 317:810-813

Dorresteijn I, Schultner J, Nimmo DG, Fischer J, Hanspach J, Kuemmerle T, Kehoe L, Ritchie EG (2015) Incorporating anthropogenic effects into trophic ecology: predator-prey interactions in a humandominated landscape. Proc R Soc B 282:20151602 
Epstein Y (2013) Population based species management across legal boundaries: the Bern Convention, Habitats Directive, and the gray wolf in Scandinavia. Geo Int Environ Law Rev 25:549-597

Epstein Y (2016) Favourable conservation status for species: examining the Habitats directive's key concept through a case study of the swedish Wolf. J Environ Law 28:221-224

Epstein Y, Darpö J (2013) The wild has no words: environmental NGOs empowered to speak for protected species as Swedish courts apply EU and international environmental law. J Eur Environ Plan Law 10:250-261

Epstein Y, López-Bao JV, Chapron G (2016) A legal-ecological understanding of favorable conservation status for species in Europe. Conserv Lett 9:81-88

European Commission (2008) Note to the Guidelines for Population Level Management Plans for Large Carnivores. Eur Comm, Brussels

European Commission (2010) Letter from Commissioner Potočnik to the Swedish Environment Minister Carlgren, Ref. Ares (2010) 919017, 7 December 2010

European Commission (2011) Answer given by Mr Potočnik on behalf of the Commission to parliamentary question E-008540/2011, 9 November 2011

European Environment Agency (2015) State of nature in the EU: results from reporting under the Nature Directives 2007-2012. Publications Office of the European Union, Luxembourg

Evans D, Arvela M (2011) Assessment and reporting under Article 17 of the Habitats Directive: Explanatory notes \& guidelines for the period 2007-2012. Eur Comm, Brussels

Fleurke FM, Trouwborst A (2014) European regional approaches to the transboundary conservation of biodiversity: the Bern Convention and the EU Birds and Habitats Directives. In: Kotze L, Marauhn T (eds) Transboundary governance of biodiversity. Martinus Nijhoff Publishers, Leiden/Boston, pp $128-162$

Freyfogle ET (2006) Conservation biology and law: only a start. Conserv Biol 20:679-680

Hiedanpää J, Bromley DW (2011) The harmonization game: reasons and rules in European biodiversity policy. Environ Policy Gov 21:99-111

IUCN Standards and Petitions Subcommittee (2016) Guidelines for using the IUCN Red List categories and criteria. Version 12. http://www.iucnredlist.org/documents/RedListGuidelines.pdf accessed 13 May 2016

Jędrzejewski W, Jędrzejewski B, Zawadzka B, Borowik T, Nowak S, Mysłajek RW (2008) Habitat suitability model for Polish wolves based on long-term national census. Anim Conserv 11:377-390

Jones G (ed) (2012) The Habitats Directive: a developer's obstacle course?. Hart Publishing, Oxford

Jorgensen K, Clemetsen M, Thoren Halvorsen, Richardson T (eds) (2016) Mainstreaming landscape through the European Landscape Convention. Routledge, London

Kaczensky P, Chapron G, Von Arx M, Huber D, Andrén H, Linnell J (eds) (2013) Status, management and distribution of large carnivores-bear, lynx, wolf and wolverine-in Europe. European Commission, Brussels

Kavčič I, Adamič M, Kaczensky P, Krofel M, Kobal M, Jerina K (2015) Fast food bears: brown bear diet in a human-dominated landscape with intensive supplemental feeding. Wildl Biol 21:1-8

Laffan B, O'Mahoney J (2004) Mis-fit, politicisation and Europeanisation: the implementation of the Habitats Directive in Ireland. OEUE Occasional Paper OEUE, Dublin

Laikre L, Nilsson T, Primmer CR, Ryman N, Allendorf FW (2009) Importance of genetics in the interpretation of favourable conservation status. Conserv Biol 23:1378-1381

Laikre L, Jansson M, Allendorf FW, Jakobsson S, Ryman N (2013) Hunting effects on favourable conservation status in highly inbred Swedish wolves. Conserv Biol 27:248-253

Liberg O, Chapron G, Wikenros C, Flagstad $\varnothing$, Wabakken P, Sand H (2015) An updated synthesis on appropriate science-based criteria for "favourable reference population" of the Scandinavian wolf (Canis lupus) population. Assignment from the Swedish Environmental Protection Agency (SEPA) Case number NV-03602-15

Linnell JDC (2013) From conflict to coexistence: insights from multi-disciplinary research into the relationships between people, large carnivores and institutions. Istituto di Ecologia Applicata, Rome

Linnell JDC (2015) Defining scales for managing biodiversity and natural resources in the face of conflicts. In: Redpath SM, Gutiérrez RJ, Wood KA, Young JC (eds) Conflicts in conservation: navigating towards solutions. Cambridge University Press, Cambridge, pp 208-218

Linnell JDC, Boitani L (2012) Building biological realism into wolf management policy: the development of the population approach in Europe. Hystrix, Ital J Mammal 23:80-91

Linnell JDC, Andersen R, Kvam T, Andrén H, Liberg O, Odden J, Moa P (2001) Home range size and choice of management strategy for lynx in Scandinavia. Environ Manage 27:869-879 
Linnell JDC, Salvatori V, Boitani L (2008) Guidelines for population level management plans for large carnivores in Europe. A Large Carnivore Initiative for Europe report prepared for the European Commission (contract 070501/2005/424162/MAR/B2)

Linnell JDC, Kaczensky P, Wotschikowsky U, Lescureux N, Boitani L (2015) Framing the relationship between people and nature in the context of European conservation. Conserv Biol 29:978-985

Linnell JDC, Trouwborst A, Boitani L, Kaczensky P, Reljic S, Huber D, Kusak J, Majic A, Skrbinsek T, Potocnik H, Hayward MW, Milner-Gulland EJ, Buuveibaatar B, Olson KA, Badamjav L, Bischof R, Zuther S, Breitenmoser U (2016) Border security fencing and wildlife: the end of the transboundary paradigm in Eurasia? PLoS Biol 14:e1002483

López-Bao JV, Blanco JC, Rodríguez A, Godinho R, Sazatornil V, Alvares F, García EJ, Llaneza L, Rico M, Cortés Y, Palacios V, Chapron G (2015) Toothless wildlife protection laws. Biodivers Conserv 24:2105-2108

McConville AJ, Tucker GM (2015) Review of favourable conservation status and Birds Directive Article 2 interpretation within the European Union. An Institute for European Environmental Policy report prepared for Natural England (No. 176)

Mehtälä J, Vuorisalo T (2007) Conservation policy and the EU Habitats Directive: favourable conservation status as a measure of conservation success. Eur Environ 17:363-375

Michanek G (2012) Strictly protected European wolf meets Swedish hunter with licence to kill. In: Backer IL et al (eds) Pro natura - festskrift til Hans Christian Bugge. Universitetsforlaget, Oslo, pp 323-345

Moser D, Ellmauer T, Evans D, Zulka KP, Adam M, Dullinger S, Essl F (2016) Weak agreement between the species conservation status assessments of the European Habitats Directive and Red Lists. Biol Conserv. doi:10.1016/j.biocon.2016.03.024

Ojalammi S, Blomley N (2015) Dancing with wolves: making legal territory in a more-than-human world. Geoforum 62:51-60

Redpath SM, Young J, Evely A, Adams WM, Sutherland WJ, Whitehouse A, Amar A, Lambert RA, Linnell JDC, Watt A, Gutierrez RJ (2013) Understanding and managing conservation conflicts. Trends Ecol Evol 28:100-109

Sanderson FJ, Pople RG, Ieronymidou C, Burfield IJ, Gregory RD, Willis SG, Howard C, Stephens PA, Beresford AE, Donald PF (2015) Assessing the performance of EU nature legislation in protecting target bird species in an era of climate change. Conservation Letters 9:172-180

Schoukens H, Bastmeijer CJ (2015) Species protection in the European Union: how strict is strict? In: Born C, Cliquet A, Schoukens H, Misonne D, Van Hoorick G (eds) The Habitats Directive in its EU environmental law context: European nature's best hope?. Routledge, London, pp 121-146

Selier SAJ, Slotow R, Blackmore A, Trouwborst A (2016) The legal challenges of transboundary wildlife management at the population level: the case of a trilateral elephant population in southern Africa. J Int Wildl Law Policy 19:101

Shine C (2005) Legal report on the possible need to amend Appendix II of the Convention for the wolf. Bern Convention Doc. T-PVS/Inf(2005)18

Stone Sweet A (2011) The European Court of Justice. In: Craig P, De Búrca G (eds) The evolution of EU law, 2nd edn. Oxford University Press, Oxford, pp 121-153

Treves A, Chapron G, López-Bao JV, Shoemaker C, Goeckner AR, Bruskotter JT (2015) Predators and the public trust. Biological Reviews (published online 3 November 2015)

Trouwborst A (2010) Managing the carnivore comeback: international and EU species protection law and the return of lynx, wolf and bear to Western Europe. J Environ Law 22:347-372

Trouwborst A (2011) Conserving European biodiversity in a changing climate: the Bern Convention, the EU Birds and Habitats Directives and the adaptation of nature to climate change. Rev Eur Community Int Environ Law 20:62-77

Trouwborst A (2014a) Exploring the legal status of wolf-dog hybrids and other dubious animals: international and EU law and the wildlife conservation problem of hybridization with domestic and alien species. Rev Eur, Comp Int Environ Law 23:111-124

Trouwborst A (2014b) Living with success - and with wolves: addressing the legal issues raised by the unexpected homecoming of a controversial carnivore. Eur Energy Environ Law Rev 23:89-101

Trouwborst A (2014c) The EU Habitats Directive and wolf conservation and management on the Iberian Peninsula: a legal perspective. Galemys-Spanish J Mammal 26:15-30

Trouwborst A (2014d) The Habitats Directive and climate change: is the law climate proof? In: Born C, Cliquet A, Schoukens H, Misonne D, Van Hoorick G (eds) The Habitats Directive in its EU environmental law context: European nature's best hope?. Routledge, London, pp 303-324

Trouwborst A (2015a) Global large carnivore conservation and international law. Biodivers Conserv 24:1567-1588 
Trouwborst A (2015b) Law and conservation conflicts. In: Redpath SM, Gutiérrez RJ, Wood KA, Young JC (eds) Conflicts in conservation: navigating towards solutions. Cambridge University Press, Cambridge, pp $108-118$

Trouwborst A (2016a) The practice of shared responsibility in relation to nature conservation. In: Plakokefalos I, Nollkaemper A (eds) The practice of shared responsibility in international law. Cambridge University Press, Cambridge

Trouwborst A (2016b) Wildlife and landscapes. In: Kulovesi K, Morgera E (eds) Research handbook on international law and natural resources. Edward Elgar, Cheltenham

Trouwborst A, Krofel M, Linnell JDC (2015) Legal implications of range expansions in a terrestrial carnivore: the case of the golden jackal (Canis aureus) in Europe. Biodivers Conserv 24:2593-2610

Trouwborst A, Fleurke FM, Dubrulle JSV (2016) Border fences and their impacts on large carnivores, large herbivores and biodiversity - an international willdife law perspective. Rev Eur, Comp Int Environ Law (in press)

Verschuuren JM (2003) Effectiveness of nature protection legislation in the EU and the US: the Birds and Habitats Directives and the Endangered Species Act. Yearb Eur Environ Law 3:305-328

Wandesforde-Smith G, Watts NSJ (2014) Wildlife conservation and protected areas: politics, procedure, and the performance of failure under the EU Birds and Habitats Directives. J Int Wildl Law Policy $17: 62-80$ 